\title{
My Favorite subject is Lengua because the teacher es un crack: translanguaging in CLIL student writing
}



PAT MOORE

UNIVERSIDAD PABLO DE OLAVIDE

pfmoox@upo.es

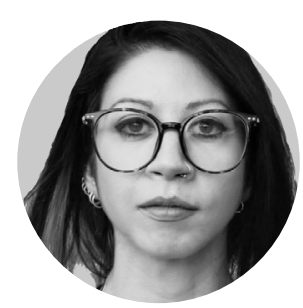

SARA LÓPEZ STOELTING

UNIVERSIDAD PABLO DE OLAVIDE

slopsto@alu.upo.es
W interpret CLIL as bilingual education inasmuch as it can help create bilinguals; and we are interested in the behaviour of emergent bilinguals. We also subscribe to the idea of holistic linguistic repertoires instead of separable languages. In this research we partially replicate research conducted by Celaya (2008) and Agustín-Llach (2009) in order to explore instances of translanguaging in CLIL writing. We focus on borrowing, translating and foreignizing. Although these instances of L1-infused language have frequently been treated as errors, we suggest teachers could more usefully consider them as naturally occurring communicative strategies: snapshots of emergent bilingualism in their students. We compare two datasets of student writing gathered at a 3.5-year interval and discuss the evolution of the students' competence as evidenced in the texts they produce.

\section{KEYWORDS:}

translanguaging; linguistic repertoires; strategies; borrowing; translating; foreignizing nterpretamos el concepto de AICLE como educación bilingüe por cuanto que contribuye a crear bilingües; y nos interesa el comportamiento de los bilingües emergentes. Nos adherimos también a la idea de repertorios lingüísticos holísticos en vez de lenguas separables. En este estudio seguimos en parte la investigación realizada por Celaya (2008) y Agustín-Llach (2009), con el fin de explorar ejemplos de translanguaging (acuñado en algunos casos como el 'translenguar') en la producción escrita de alumnado de AICLE. Nos centramos en tres categorías de lenguaje infundido por la L1: préstamo, traducción y extranjerización. Si bien se han considerado anteriormente como errores, sugerimos que sería más útil que el profesorado los tratase como estrategias comunicativas que surgen de manera natural, es decir, como manifestación del bilingüismo emergente del alumnado. Comparamos dos bases de datos de producción escrita del alumnado recogida en un intervalo de 3,5 años y analizamos la evolución de su competencia, tal y como se evidencia en sus textos.

translenguar; repertorios lingüísticos; estrategias; préstamo; traducción; extranjerización 


\section{Introduction}

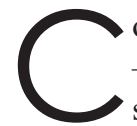
ontent and Language Integrated Learning - CLIL - is often presented as 'bilingual education' yet to some that can feel like a misnomer - is it really bilingual? (See, for example, the discussion in Pena Díaz and Porto Requejo 2008, pp. 157-8). One possible solution to the dilemma is to consider 'bilingual education' as a compound rather than as an adjective + noun construction. In the same way that 'teacher education' is understood to mean the training/development of teachers, 'bilingual education' can be interpreted as the development of bilinguals and this is the approach adopted in this article. We position the students in the study as emergent bilinguals - bilinguals in the making (for further discussion see Moore and Turnbull, in press).

Hamers and Blanc (1989) make a distinction between societal 'bilingualism' and individual 'bilinguality' which will be useful for this discussion. The idea that bilinguality is fundamentally different from monolinguality is hardly new. Grosjean (1989) argued that the bilingual is not two monolinguals in one, rather that they should be considered "as a unique and specific speaker-hearer" (p. 3). This aligns with Cook's (2007) envisaging of multi-competence and "the complexity of a mind with two languages compared to the simplicity of a mind with one" (p. 242). Cummins $(1979,1980)$ posited the Dual Iceberg Model to account for underlying interdependence between a speaker's languages. Indeed, Butzkamm (1998, p. 83) warned us that it was psychologically unsound to attempt to separate the languages of students in a 'foreign' language scenario.

We should point out that while Cook, Cummins and Butzkamm cited above talk of languageS - as separable and countable entities, more recent research has started to question this idea. For example, as Blackledge and Creese (2014) observed, "the idea of 'a language' may be important as a social construct, but it is not suited as an analytical lens through which to view language practices" (p. 1). In fact, the Common European Framework of Reference (CEFR) also promoted this idea when it accounted for multicompetence as "not seen as the superposition or juxtaposition of distinct competences, but rather as the existence of a complex or even composite competence on which the user may draw" (Council of Europe 2001, p.168).

Although in this article we use the terms L1 and L2, we are actually grappling with 'cognitive dissonance' (Moore \& Nikula 2016, p.3) while doing so. The idea of 'translanguaging', which was born in (Welsh) bilingual classrooms but has now moved out into society in general, provides a heuristic which can assist us. For example, Otheguy, García \& Reid (2015) contrast external named (countable) languages with internal, holistic, linguistic repertoires - (uncountable) language. Translanguaging encompasses transfer, translation, loanwords, borrowing and code-switching, lexical coinages (aka foreignization), pidgins and fusions (e.g., Spanglish). Essentially a behavioural phenomenon, it implies a speaker, or in this case writer, drawing on their full linguistic repertoire when engaged in making meaning (communicating). This re-positions the L1 in the endeavour of learning/acquiring additional languages since, through a translanguaging lens, it is no longer viewed as error, 'interference', or as a 'resort' or something to 'fall back on'; it is perceived as literally an integral part of the speaker/writer's repertoire, indeed a potentially valuable tool. If we consider the close typological links between Spanish and academic English, which is far more 'Latinate' than spoken English, we could even suggest that Spanish CLIL learners studying content subjects in English are endowed with a rich resource to mine.

In this article we explore translanguaging practices in the written output of secondary school students in a CLIL programme in Andalucía. We focus on three forms of translanguaging - borrowing, translation and foreignizing and their use by the students (the ways they manipulate their repertoires). We are interested which strategies the students employ rather than how often they do so and, since this is part of a longitudinal study, in how their behaviour evolves over time, as their L2 competence increases and bilinguality emerges.

The article is organised as follows: first we acknowledge some of the more relevant research, both from within the field of CLIL and from the wider scope of L2 writing studies. We discuss the criteria we employ to explore the students' writing and then we present the context within which the research was conducted. When presenting the results, we compare findings from two sets of data (gathered at a 3.5-year interval) and we discuss implications for teachers. Our main goal is to encourage teachers to question and re-evaluate notions of 'error' in the written production of emergent bilinguals.

\section{Previous research}

et us first recognise that CLIL was never intended to replace foreign language classes; rather it was to complement them, by providing the massive input and opportunities for output and interaction that are generally

\section{${ }^{66}$ In this article we explore translanguaging practices in the written output of secondary school students in a CLIL programme in Andalucía. We focus on three forms of translanguaging - borrowing, translation and foreignizing -, and their use by the students.'}


deemed necessary for L2 development. Yet it should come as no surprise to find that CLIL, especially at the outset, had to address the perennial conundrums of foreign language teaching (FLT), among them the L1 question.

In FLT there has been much debate over whether the L1 is friend or foe in the endeavour but it seems safe to say that nowadays most researchers have accepted its inevitability and are more focused on exploring its roles and maximising its potential (see for example Hall \& Cook 2012; Littlewood \& Yu 2011). It might initially be surprising to see Hall and Cook criticise CLIL as a "notable manifestation of diehard monolingualism" (2012, p. 297). CLIL, they argue, both aligns itself too closely with "the old SLA view that exposure and attention to meaningwill be sufficient factors for language learning success" (p. 298) and leans too heavily on North American content-based models of immersion. They cite Marsh's (2002) assertion that L1 use should 'wither away' as L2 competence grows. From that perspective, perhaps, Hall and Cook's criticism is not unjustified.

More recently, however, CLIL research has become more concerned with and interested in the L1 question. There is a growing body of research looking at the L1 in CLIL classroom communication (see, for example, Lasagabaster 2017; Lin 2015; Pavón Vázquez \& Ramos Ordóñéz 2018; San Isidro \& Lasagabaster 2018; Skinnari \& Nikula 2017); including from a translanguaging perspective (Lin \& He 2017; Moore \& Nikula 2016; Nikula \& Moore 2019; Tsuchiya 2019). We could tentatively suggest that CLIL is taking a 'multilingual turn'.

From the perspective of writing, Falk (2015) bemoans the fact that so much research in CLIL contexts has side-lined the L1 and focused only on the L2; arguing that "we should take the whole language situation into consideration" (p. 316). That said, while not theoretically positioned as translanguaging research, CLIL researchers have explored the L1 question in CLIL student writing. For example, Lorenzo and Moore (2010) compared texts written in Spanish and English by CLIL students and found clear signs of transfer from the L1 into the L2, particularly from the perspective of rhetorical moves such as hedging or reformulation. Another take on the question comes from Maxwell-Reid (2010) who compared texts written in Spanish by students enrolled in a CLIL programme with texts written by students in monolingual (Spanish) courses and found evidence of L2 (English) influence on L1 (Spanish) output in the CLIL cohort, particularly with regards to text organisation and clause complexes.

Researchers interested in L2 writing have turned to CLIL students to provide comparative samples. For example, building on studies initially conducted within the Barcelona Age Factor project (see Muñoz 2006 for an overview, and Navés et al. 2005 for an example), Celaya (2008) conducted longitudinal research comparing the written output of CLIL learners with 'regular' (i.e. Spanish monolingual) learners at a two-year interval - in grades 5 and 7. She was particularly interested in two aspects of lexical transfer: outright borrowing and inventions (a merging of L1 and L2 to produce novel items; see the discussion of foreignization below), which she posited as 'compensatory strategies'. Her initial assumption was a) that L1 use would decrease over time and b) that the mainstream learners would lean more heavily on their L1 (borrowing), whereas CLIL learners, bolstered by the extra exposure that the approach entails, would produce more inventions. The first supposition held. She was surprised, however, to find that although their production did increase slightly with time, both cohorts produced comparable (and low) quantities of inventions. She tentatively attributes this to the mode of data-gathering, suggesting that the spontaneity of oral production might be more conducive to the production of inventions.

Another researcher who has explored the question of L1 transfer in L2 writing is Agustín-Llach (2009). Having previously looked at EFL learners in general (e.g., AgustínLlach 2007), she turned her attention to CLIL with her 2009 study. She compared two groups of 30 students, one CLIL, one mainstream. The two groups had both started to learn English at an early age (3 years old) but initial language testing confirmed that the CLIL group, having had more contact with English, were more advanced in English than their counterparts. Learners were given an in-class writing assignment which Agustín-Llach then analysed for three types of what she denotes 'L1 influenced lexical errors': borrowing, coinage (more or less equivalent to Celaya's 'inventions') and calque (translations). Overall, she found higher instances of all three in the mainstream learners' texts, but her analysis went beyond the purely quantitative. While the CLIL learners' texts featured fewer 'errors' overall, the results chimed with those of Celaya (2008) in that there were far fewer borrowings in the CLIL texts in comparison to coinages. Furthermore, Agustín-Llach found that there were more calques than coinages, which could possibly be equated with a developmental curve in L1 use in novice L2 writers: from borrowing, through coinage to calque.

Agustín-Llach seems to come out in favour of CLIL. She acknowledges that competence obviously plays a part in determining the results, yet suggests the differences go beyond questions of proficiency: non-CLIL learners, she speculates, perceive of English as a school subject and writing an essay as a school exercise, whereas for CLIL learners English represents "a tool to communicate and to transfer knowledge" and thus writing an essay provides opportunity for "meaningful interaction" (p.123).

That said, from a translanguaging perspective, there is a potentially confounding factor, which Agustín-Llach does acknowledge (p.125), but does not really explore: the CLIL group from the Basque country, were already bilingual - being Spanish/Basque speakers acquiring an L3, while the mainstream group, from La Rioja, were monolingual Spanish speakers acquiring an L2. We would expect this to impact on learner behaviour. The two groups are thus not comparable as emergent bilinguals. 


\section{Borrowing, Translating and Foreignizing in CLIL writing}

$\mathrm{T}$ his research is a partial replication of Celaya (2008) and Agustín-Llach (2009). Both Celaya and AgustínLlach compared CLIL and non-CLIL cohorts, yet we focus only on CLIL writing. Like Celaya we are comparing texts produced at an interval. In our case the interval is slightly longer -3.5 years; the $1^{\text {st }}$ data collection point was just two months into the participants' first year of secondary education and the $2^{\text {nd }}$ time at the end of their third year. Like Agustín-Llach we focus on a trio of features -Borrowing, Translating and Foreignising (although we use different names, see discussion below).

We must acknowledge that these features have frequently been considered 'errors'- for example, James (1998) grouped the three under the heading of 'interlingual misformation errors' and Agustín-Llach (2009; 2015), while recognising the inevitability of L1 influence in Ln acquisition, still used the term 'lexical errors' (see also DağdevirenKırmızı 2018; Hemchua \& Schmitt 2006, among others). From an emergent bilingual, translanguaging perspective, however, we can interpret them as creative forms of pre-emptive repair: the writer employing their full linguistic repertoire in order to convey meaning and avoid communication breakdown. As noted above, Celaya (2008) regards them as compensatory strategies (see Oxford 1994 for a useful overview of strategies in language learning, and PsaltouTzoysy, Alexiou \& Mattheoudakis 2014 for a discussion of strategy use in CLIL). That said, adopting a translanguaging perspective, we can go even further and acknowledge the likelihood of the L1 coming into play for multiple reasons not least humour and/or solidarity - and not just as a repair mechanism.

Regarding our choice of terminology, we have tried to use terms which are familiar, yet we do need to briefly discuss their application in this study. To start with, Borrowing implies inserting L1 'as is' into L2 (or, indeed, L2 into L1 since nowadays the relationship between the languages in a speaker's repertoire is understood as bi-directional -Dworin 2003; Marian \& Kaushanskaya 2007; Pavlenko \& Jarvis

\section{${ }^{66}$ Adopting a}

translanguaging perspective, we can go even further and acknowledge the likelihood of the L1 coming into play for multiple reasons not least humour and/or solidarity - and not just, as a repair mechanism.
2002). As such it is related to the concept of code-switching although as Lipski (2005) noted, the distinction can be fuzzy: "Code-switching or Borrowing? No sé so no puedo decir, you know". In this case we are interested in what is variously known as nonce (Sankoff, Poplack \& Vanniarajan 1990) or ad hoc (Schmid 1993) borrowing - the spontaneous use of items from the students' L1, as distinct from 'loans' which may have started out as a borrowing, but which have become established (as is the case with the rrack $^{1}$ in the title of this article and terms such as piercing, link or catering in contemporary European Spanish).

We employ the term Translating to cover what have variously been called 'loan translations' (e.g., Meriläinenet al. 2016), 'instant translations' (e.g., Heltai 2004) and 'calques' (e.g., Agustín-Llach 2009; DağdevirenKırmızı 2018). We avoid calque, however, because in some quarters the term is used to describe more established translations, such as rascacielo for skyscraper or baloncesto for basketball, and we want to emphasise the spontaneous, improvisational nature of the translations we find in the student texts. Nor do we limit our discussion of translation to lexical items, we include the 'translation' of features such as word order, collocations and chunks; as well as the incidence of false cognates (see discussion below).

A wealth of potentially competing labels exists to describe what we are here calling Foreignizing. Dewaele (1998), who employs the term 'lexical inventions' (and inspired Celaya to follow suit in 2008), takes a descriptive stance by referring to them as "lexemes which are morpho-phonologically adapted to the target language but never used by native speakers" (p. 471). Agustín-Llach (2010) adopts a similar attitude with her gloss of 'coinages' as “adaptations of L1 words to the phonographemic rules of the L2" (p. 3). She also notes that Ringbom (1983) preferred 'relexification' (Agustín-Llach 2009 , p. 118), but this term appears to be closely related to creole genesis (see DeGraff 2002). Creese and Blackledge (2010), in their study of complementary schools in the UK, prefer 'heteroglossic terms', noting that they are "likely to reflect the linguistic practices of [the teacher] beyond the classroom, indexing other language ecologies" (p. 110); in other words hors classroom bilinguality. One of the main reasons we opted for the term 'foreignizing' is that it appears in the CEFR where it is included as a compensatory strategy at B1 level: "Can foreignize a mother tongue [sic] word..." (2001, p. 64).

Marian and Kaushanskaya (2007) distinguish between 'overt' borrowing and 'covert' transfer. From this perspective both translation and foreignizing would be considered transfer since although implicitly (covertly) informed by the L1, they do not involve explicit (overt) L1 use (or borrowing). In a similar vein, Ringbom (2001) observed that while borrowing does not involve the L2, other strategies, such as translating or foreignizing, imply interaction between L1 and L2 and thence suggest a higher degree of competence (in Celaya 2008, p.45). Previous research has found, perhaps unsurprisingly, that overt L1 use decreases with proficiency (Agustín-Llach 2009; Celaya 2008; Navés et al. 2005) yet it 
should be noted that a lot of this research seems influenced by a (monolingual) target language perspective, rather than a descriptive bilingual stance.

\section{Context, participants and data-gathering}

$\mathrm{T}$ he data for the present study was obtained as part of a longitudinal project designed to explore the idea of emergent bilinguality amongst CLIL students at a semirural state secondary school in Andalucía. In 2014, when the project began, the school was still offering CLIL bilingual sections as an option, and so the students who participated two groups - had all opted into the programme.

When gathering longitudinal data regarding foreign language performance in a (Spanish) secondary school, there are all manner of potentially confounding variables that might affect results. As noted above, students had all explicitly chosen the bilingual streams and thus may have been more motivated regarding English, but since we are not comparing CLIL and non-CLIL students we can disregard this question. That said, aside from day-to-day variables like attendance or mood, the potential for confounding variables is massive: the fact that classes are decreasingly likely to be monolingual (see European Commission 2015) means a variety of L1s may be in play; lots of children receive extra tuition outside school, some from paid instructors, others from family members (for example the groups included twin sisters whose father had weekly English classes and who transferred what he learnt to his daughters); in most (if not all) classes there are students who are repeating the year, plus students come and go.

A total of around 80 students participated in the datagathering over the four-year period but less than $50 \%$ of them contributed data consistently. For the purposes of this study, therefore, the sole selection criterion was that the learner had participated in the written data collection in both 2014 and 2017. This gave us 25 students and 50 texts. Although the two groups overall did include students whose L1 was not Spanish, none of them contributed to both the 2014 and 2017 data so this was another variable we could discount. We are not factoring any other variables (gender, age, extra tuition, etc.) into the equation.

Students were given 45 minutes to write on one of three topics. There was no pre-teaching of any kind, discussion of models or similar. Our interest was in spontaneous production. In the first data-gathering (2014), conducted only a month after the beginning of the students' first year, general topics were selected. They could choose between "My favourite subject", "Spain's new king", and "The World Cup" ("My favourite subject" proved to be the most popular choice by far). In subsequent data-gathering sessions, conducted just prior to the end of the school year in May/June, topics were suggested by the content teachers and were related to lessons and subjects which had recently been covered in class. In 2017 the topics were: "Social Networks", "The Importance of Recycling" and "The Advantages and Disadvantages of
Public Transport". Data-gathering was conducted in the IT room and so students had to write on computers but did not have internet access. Despite requests from the students, no guidelines were given regarding the size of the text they needed to produce. They were also given free rein regarding fonts, colours, etc.

\section{Results and Discussion}

B efore looking for evidence of strategy use in the students' writing, we can make some observations regarding the evolution of the texts themselves. As noted above, the data-gathering was conducted in the IT room and it was obvious that there were differing degrees of computeracy (ability to read/write, etc. via computer) among the cohort. For some students, composing text on a computer was a novel process. Many were unaware of spellcheckers. In the 2014 batch, paragraphs were rare; many of the students started a new line for each sentence. Indeed, the fresh line was often the signal of a new sentence: full stops were in short supply.

If we remember that the first data-gathering, in 2014, was conducted only one month after starting secondary education, it comes as little surprise to find that many of the first texts were very colourful:

\section{MY FAVOURITE SUBJECT}

My favourite subject is Phisical Education. I love this subject because I like go to the gym and I like play sports. I do P.E two times a week, but I do sports everydays but at differents hours. My teacher of Phisical Education is Pablo.

I like P.E when we do funny's games or sports. We do some exercises before the others sports.

\section{LOVE PHISICAL EDUCATION}

Figure 1. A colourful example from the 2014 sample

That said, over the process, texts became increasingly conformist and by 2017 all were monochrome and both punctuation and paragraphing were more frequent. From this perspective, we can see the students gradually assimilating academic norms.

Not giving them a specified word count meant that they were free to write as little or as much as they chose (within the time limit) and there was considerable variation in text lengths. A simple comparison, however, shows us that the mean length of texts doubled over the two-year period.

\begin{tabular}{lcccr}
\hline Year & No. Ss & Min. & Max. & Mean \\
2014 & 25 & 26 & 173 & 76.64 \\
2017 & 25 & 49 & 250 & 144.84 \\
\hline
\end{tabular}

Figure 2. Minimum, maximum and mean word counts 
The question of text length is not a major concern here as the intention is not a detailed quantitative analysis (incidence of each strategy per $\mathrm{X}$ words), rather we are interested in how many students employ each of the strategies (incidence of each strategy per student). As Figure 3 below illustrates, in 2014 six of the students did not use any of the three strategies; ten of them used one and nine of them used two different strategies. In 2017 only 4 of the students used none of the strategies, eighteen of them employed one, one of them used two and two of them used all three. Overall then we can see that strategy-use increases, albeit not significantly.

\begin{tabular}{|lll}
\hline No. of strategy types employed by Ss & 2014 & 2017 \\
\hline 0 & 6 & 4 \\
1 & 10 & 18 \\
2 & 9 & 1 \\
3 & 0 & 2 \\
\hline
\end{tabular}
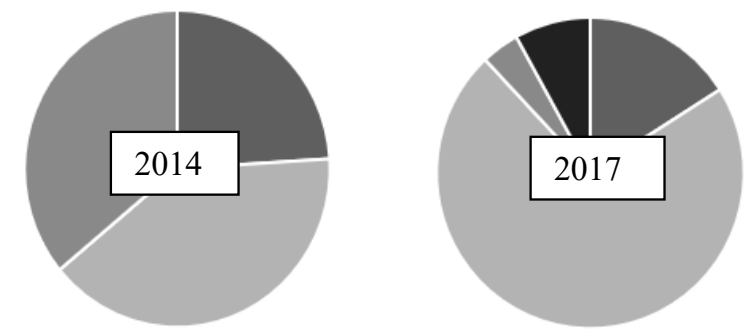

Figure 3. Number of strategies employed by students in the two rounds of data-gathering

What of the different strategy types? If we break them down, we can see that while the use of borrowing decreased from nine students in 2014 to only three in 2017, the use of translation and foreignization increased, the former going from eleven to thirteen students and the latter from seven to eleven.

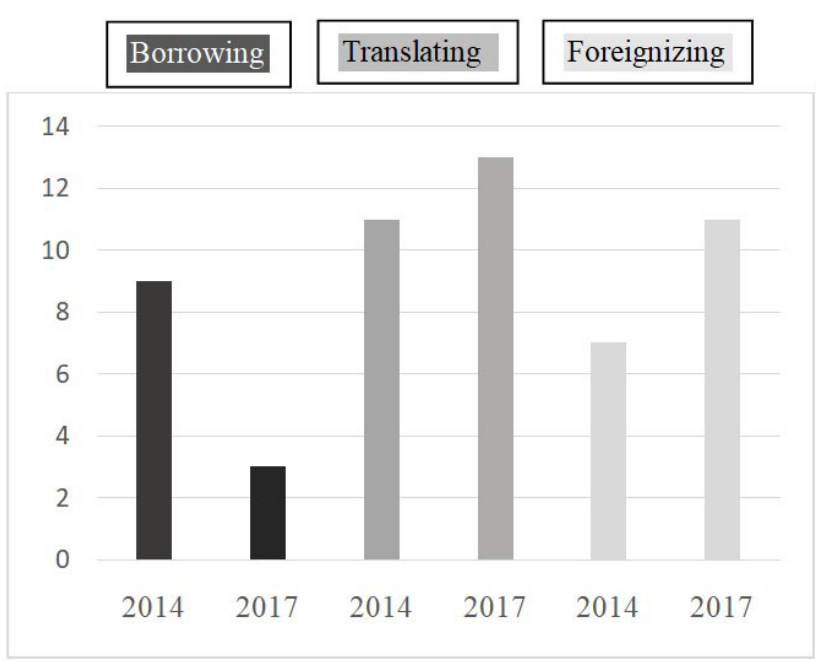

Figure 4. Breakdown of strategy types employed by students in the two rounds of data-gathering
Let us look at the categories in a bit more detail. We illustrate the discussion with extracts from the students' texts (the code in brackets identifies student/year) and provide translations of L1 in the texts in square brackets underneath.

\section{Borrowing}

While it is often claimed that borrowings are typically nouns (e.g., Myers-Scotton 1995; Marian \& Kaushanskaya 2007), in the 2014 sample there are several exceptions to that rule, and we find verbs (manda, hacemos) and adverbs (sobretodo) too. We do need to remember that these students had only been at the school for a month and, although Andalusian guidelines laudably attempt to ensure progression between bilingual sections in primary and secondary education, some of the students had come from monolingual primary education and their L2 competence was fairly limited. That said, we also find borrowings such as profesor for teacher, which is only used in higher education contexts in 'native speaker' English, but which is very common in L2 English, aka English as an International Language/Lingua Franca (EIL/ELF), the de facto target language (Seidlhofer 2003) for the students in question.

Although they are flagged in italics in the extracts here presented, in the original texts L1 borrowing was only rarely acknowledged as such - as in the bracketing of acabo below.

(S02/14) My favorite subject is $\boldsymbol{E} . \boldsymbol{F}[\mathrm{PE}]$ because my teacher is my entrenador [coach] de volleyvall

(S07/14) ...the teacher manda [sets] very ejercicios [exercises]

(S08/14) The profesor [teacher] is bueno [good] and hacemos [we go on] excursions

(S14/14) ...because every body starts talk and (acabo) [l end up] with pain of head

(S20/14) I like sport sobretodo [especially] orientation.

In contrast, in the 2017 sample we only find three students employing outright borrowing. So, in line with previous longitudinal research (Celaya 2008; Navés et al. 2005) we find a clear decrease in this strategy. They are all examples of what Laufer (1991) called 'synformic confusion' - when the root of the words in both languages in shared. Interestingly, they all involve nouns; so perhaps we could also say that it is more conformist or felicitous borrowing than in 2017.

(S13/17) Another positive aspect of social networks is that you can help people by giving money to an ONG [NGO]

(S15/17)...which can be good or bad depend of situacion [situation] 
(S25/17) The social networking is the medio [media] of communication from the people

Tying in with the idea of shared roots, and the notion of typological proximity discussed above, we would suggest that one of the biggest differences between the borrowings in 2014 and 2017 is that while only a bilingual English/Spanish speaker would understand the borrowings in 2014, even a monolingual English speaker could probably understand all three 2017 texts. From that perspective, might we say that the students have become more effective communicators?

\section{Translation}

Let us turn to translation. In the examples below we can see that the students have translated literally from Spanish. In the first example we have word order, in the second and third collocations (hacer una pregunta and poner dibujos). These are examples of what Hall (2002) calls 'parasitic strategy', whereby early stage learners apply L1 'rules' to L2 output. This can be appreciated as an intuitively logical process, merging new with old.

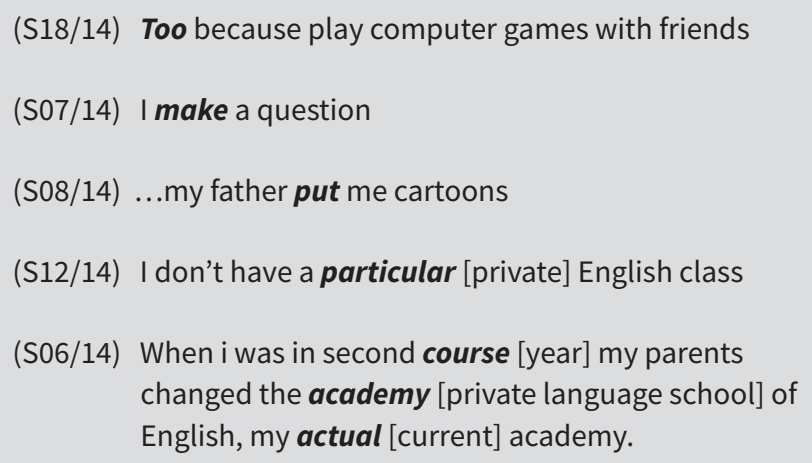

False cognates such as particular and actual(ly) can be considered translations too. Actually, most of the translations in the 2017 sample consist of false cognates. Again, we can interpret this as progress.

(S10/17) Actually [Nowadays] is easier to study than some years ago...

(S16/17) Hackers can see your direction [address] and your personal data

(S07/17) Cyberbullying you can be insulted for other people and hurt your sentiments [feelings]

(S22/17) The bus is very economic [economical]

In both 2014 and 2017 samples we again find features which are typical of Spanish L1 English such as academy for private language school and actual(ly) meaning current.
While we are mostly focusing on single word items, from the perspective of translation it is worth noting that the translation of chunks also increases over the period. In the 2014 we find a couple of translated chunks such as

\section{(S11/14) ...exam of natural science...}

But in 2017 there are more such examples. This could be taken as a sign of progress; since it suggests students are no longer composing text word by word. The first example is a translation of llevó a un incremento (led to an increase) and the second from llevar a la muerte (led to death).

(S06/17) So this carried an increase of the use of transport

(S13/17) It is more common in teenagers and, in some cases, it brought them to the death.

From a teacher's perspective, looking at these examples of translation reinforces the need to work with chunks, to include common collocations and set expressions.

\section{Foreignization}

We can perceive of foreignization as a skill, since it implies applying target language morphosyntactic rules to L1 roots, indeed, as noted above, the CEFR considers it a skill typical of B1 level students.

(S01/14) Technologie [Technology] I like because learn things new

(S12/14) ...because my mother is more timide [timid/shy] than my father

(S25/14) I like music because divert [it's fun]

As noted above, foreignization increased over the period. The 2017 examples are interesting from various perspectives. Repetition of various items, such as privacity (privacy) and informated (informed) demonstrate the inherent attractive logic behind the students' choices. They could also serve as flags for the teacher, signalling language which is worth clarifying in whole class feedback (see William and Leahy 2015) because it could serve multiple learners. This would be an example of what Drier (2004) calls 'ghostbusting'.

(S12/17) ... with social media your privacity and your personal data is in danger

(S24/17) You must have attention to your privacity... 
(S05/17) ...people haven't privacity from the hackers. (S14/14) You can search a lot of things in internet and be informated

(S20/17) You can be informated about things that are happening in your country

(S1/2017) Cyberbulling: Is when a person is acosated by other person by internet. [harassed]

( $\mathrm{S} 21 / 17)$ We can't know who is the person that is accosing [harassing] because is annonymus

(S01/17) Social networking is good because can help a very people. But is peligrous [dangerous] because can hacking your computer

All of these examples underpin the idea that students are gradually assimilating English morphosyntax. In the final example, we have to assume that the student was at least halfway to their target, since they correctly used the suffix even if the root remained beyond their grasp.

As noted previously, a lot of research into L1/L2 relationships in learner output has considered the kind of behaviour we have been discussing here as error (e.g., Agustín-Llach 2009; Dağdeviren Kırmızı 2018; Hemchua \& Schmitt 2006; James 1998) but we prefer to interpret it as translanguaging:

"[A]ct[s] performed by bilinguals of accessing different linguistic features or various modes of what are described as autonomous languages, in order to maximise communicative potential.” (García 2009, p. 141)

This represents an important decision for (CLIL) teachers. Take the sentence below. A teacher who allowed the notion of error to dominate might be blinded by three 'mistakes' in just one sentence.

(S08/17) Or cyberbullying: someone is acosed by someone in the social media and normally the buller is anonime.

Yet, if we switch the focus and adopt a more constructive stance, we can see that the writer:

- is writing complex sentences using punctuation and conjunctions to link clauses

- is using adverbs to temper assertions (modality/hedging)

- is correctly producing passive structures

- appears to have assimilated the -ed form for participles (acosed)
- is using -er to 'make' doers (buller -a word that is tricky because in English the verb and noun are actually the same - bully)

- has made an intelligent guess in trying to translate anónimo

At times we suspect a 'lucky guess factor' comes into play. It is possible that the two students below 'acquired' the terms they used through CLIL classroom discussion of the content topics (social networks in technology and transport in social science) but, given their typological similarity to Spanish items, we are equally inclined to think that the two examples might well represent felicitous translanguaging; what Drier (2004 p.125) calls 'friendly ghosts'.

(S04/17) An example of an advantage is the connectivity between people from everywhere

(S22/17) The maritime transport is used for long distances

\section{Conclusions}

This research partially replicates L2 writing research done by Celaya (2008) and Agustín-Llach (2009) exploring instances of L1-infused meaning-making in CLIL secondary writing. Like Celaya, we found overt L1 borrowing decreased over the 3.5-year period while covert L1 influences increased. Like Agustín-Llach, we found that translations outnumbered foreignizations (coinages in her study), although in our case the increase in translations and foreignizations was equal.

Agustín-Llach (2009, p.123) claimed that it was difficult to spot positive transfer. But that is attributable to her decision to classify the phenomena as errors. If we re-focus, through a translanguaging lens, we can appreciate all of the L1infused language in our samples as communicative intent, as the constructive attempts of emerging bilinguals to forge meaning.

We describe the three foci of our analysis, Borrowing, Translating and Foreignizing, as creative pre-emptive repair and as strategies but we do not mean to imply that they are necessarily conscious. That said, given the strong typological links between Spanish and English, perhaps explicitly highlighting similarities between L1 and TL could be helpful. In 1979, Kellerman introduced the concept of 'psychotypology' which he defined as "the perceived distance between two languages". 'Perceived' is important here because what Kellerman describes relies on learner beliefs. This suggests that ensuring that learners are aware of typological similarities and encouraging them to take a leap of faith sometimes could be beneficial. In a university CLIL scenario, Adamson and Coulson (2015) found that awareness-raising around translanguaging practices (not limited to typological similarities) was popular with students 
and led to gains in writing.

As a final reflection, and an avenue which could be followed in future research, it is worth noting that the students were never explicitly instructed to only write in English and the datagathering was conducted in bilingual 'mode' - all the adults present were translanguaging while giving instructions, etc. So, we could surmise that students were (unconsciously?) writing for a bilingual audience. Moore (2018) identifies what she termed 'bilingual interaction' in the writing of her advanced level English students who demonstrated sensitivity to their target audience's linguistic repertoire in their writing, for example by providing translations for terms they predicted their reader might not be familiar with. The students in this study knew that the people who would be reading their essays were bilingual and so may well have used strategies accordingly. In Agustín-Llach's (2009) study, the writing task involved writing a letter to an English host family and she suggested that this may have affected L1 use, since at least some of the learners interpreted it as a genuine communicative task (p. 124). It follows that it would be interesting to give respondents two writing tasks, one for a monolingual audience and one for a bilingual audience to see whether, and if so how, their behaviour changed.

\section{Notes}

1 We are, of course, grateful to the student who serendipitously provided us with the title of this article. Ser un(a) crack in Spanish means to be really good at something. Although 'crack' is considered English (with Germanic origins), ser un(a) crack might actually have come via French, where être un crack has the same meaning as in Spanish. Neither the Cambridge nor the Oxford online dictionaries include an entry for 'be a crack', although it does exist as a colloquial expression denoting that someone is a lot of fun. Crack is also an adjective, however, which can collocate with a limited number of nouns and then does imply skill: a 'crack shot' and a 'crack hand at X' are the two examples which first spring to mind. So, albeit tortuously, the Spanish expression does have links with English. But when the student wrote My favorite subject is lengua because the teacher es un crack, he was arguably using it 'Spanishstyle'.

https:/dictionary.cambridge.org/dictionary/english/ crackhttps://en.oxforddictionaries.com/definition/crack

\section{References}

Adamson, J., \& Coulson, D. (2015). Translanguaging in English academic writing preparation. International Journal of Pedagogies and Learning, 10(1), 24-37.
Agustín-Llach, M. P. (2007). Lexical errors as writing quality predictors. Studia Linguistica, 61(1), 1-19.

https://doi.org/10.1111/j.1467-9582.2007.00127.x

Agustín-Llach, M. P. (2009). The role of Spanish L1 in the vocabulary use of CLIL and non-CLIL EFL learners. In Ruiz de Zarobe, Y. \& Jiménez Catalán, R.M. (Eds.), Content and Language Integrated Learning: Evidence from research in Europe, 122-129. Multilingual Matters. https://doi.org/10.21832/9781847691675-010

Agustín-Llach, M. P. (2010). An Overview of variables affecting lexical transfer in writing: A review study. International Journal of Linguistics, 2(1), 2-17.

https://doi.org/10.5296/ijl.v2i1.445

Agustín-Llach, M. P. (2015). Lexical errors in writing at the end of primary and secondary education: Description and pedagogical implications. Porta Linguarum, 23, 109-124.

http://hdl.handle.net/10481/29120

Blackledge, A., \& Creese, A. (2014). Heteroglossia as practice and pedagogy. Springer.

https://doi.org/10.1007/978-94-007-7856-6_1

Butzkamm, W. (1998). Code-switching in a bilingual history lesson: The mother tongue as a conversational lubricant. International Journal of Bilingual Education and Bilingualism, 1(2), 81-99.

https://doi.org/10.1080/13670059808667676

Celaya, M. L. (2008). I study 'Natus' in English: lexical transfer in CLIL and regular learners. In Monroy, R. \& Sánchez, A. (Eds.), Actas del XXV Congreso de Aesla: 25 Años de Lingüística en España: hitos y retos, 43-49. Murcia: RESLA/Universidad de Murcia.

Cook, V. (2007). The Goals of ELT: Reproducing native speakers or promoting multicompetence among second language users? International Handbook of English Language Teaching, 237-248. Springer.

https://doi.org/10.1007/978-0-387-46301-8_18

Council of Europe. (2001). The Common European Framework for Languages: Learning, Teaching, Assessment. Modern Languages Division. https://rm.coe.int/1680459f97

Creese, A., \& Blackledge, A. (2010). Translanguaging in the bilingual classroom: A pedagogy for learning and teaching? Modern Language Journal, 94(1), 103-115. https://doi.org/10.1111/j.1540-4781.2009.00986.x

Cummins, J. (1979). Cognitive/academic language 
proficiency, linguistic interdependence, the optimum age question and some other matters. Working Papers on Bilingualism, 19, 121-129.

Cummins, J. (1980). The construct of language proficiency in bilingual education. In Alatis, J.E. (Ed.), Georgetown University Round Table on Languages and Linguistics, 81-103. Georgetown University Press.

Dağdeviren Kırmızı, G. (2018). Lexical errors and linguistic calques as lexical transfer in EFL writing: A case study. Başkent University Journal of Education, 5(2), 99-106.

DeGraff, M. (2002). Relexification: A reevaluation. Anthropological Linguistics, 44(4), 321-414.

Drier, B. (2004). Ghostbusting: On consciousness, psychotypology, and the role of explicit instruction. Nagaoka University of Technology Bulletin of Language Sciences and Humanities, 18, 117-130.

Dworin, J. E. (2003). Insights into biliteracy development: Toward a bidirectional theory of bilingual pedagogy. Journal of Hispanic Higher Education, 2(2), 171-186. https://doi.org/10.1177/1538192702250621

European Commission. (2015). Language teaching and learning in multilingual classrooms.

https://op.europa.eu/en/publication-detail/-/publication/ c5673e19-c292-11e6-a6db-01aa75ed71a1

Falk, M. L. (2015) English and Swedish in CLIL student texts. The Language Learning Journal, 43(3), 304-318. https://doi.org/10.1080/09571736.2015.1053280

Grosjean, F. (1989). Neurolinguists, beware! The bilingual is not two monolinguals in one person. Brain and Language, 36(1), 3-15.

https://doi.org/10.1016/0093-934X(89)90048-5

Hall, C. J. (2002). The automatic cognate form assumption: Evidence for the parasitic model of vocabulary development. IRAL - International Review of Applied Linguistics in Language Teaching, 40(2), 69-87.

https://doi.org/10.1515/iral.2002.008

Hall, G., \& Cook, G. (2012). Own-language use in language teaching and learning. Language Teaching, 45(3), 271308. Cambridge University Press.

https://doi.org/10.1017/S0261444812000067

Hamers, J. F., \& Blanc, H. A. (1989). Bilinguality and bilingualism. Cambridge University Press.

Heltai, P. (2004). Ready-made language and translation.
In Hansen, G. Malmkjær, K. \& Gile, D. (Eds.), Claims, changes and challenges in translation studies, 51-71. John Benjamins.

https://doi.org/10.1075/btl.50.06hel

Hemchua, S. \& Schmitt, N. (2006). An analysis of lexical errors in the English composition of Thai learners. Prospect, 21(3), 3-25.

James, C. (1998). Errors in language learning and use: Exploring error analysis. Longman.

Kellerman, E. (1979). Transfer and non-transfer: Where we are now. Studies in Second Language Acquisition, 2(1), 37-57.

https://doi.org/10.1017/S0272263100000942

Lasagabaster, D. (2017). 'I always speak English in my classes': Reflections on the use of the L1/L2 in Englishmedium instruction. In Llinares, A. \& Morton, T. (Eds.), Applied Linguistics Perspectives on CLIL, 251-267. John Benjamins.

https://doi.org/10.1075/llt.47.15las

Laufer, B. (1991). Some properties of the foreign language learner's lexicon as evidenced by lexical confusions. IRAL - International Review of Applied Linguistics in Language Teaching, 29(4), 317-348.

https://doi.org/10.1515/iral.1991.29.4.317

Lin, A. M. Y. (2015). Conceptualising the potential role of L1 in CLIL. Language, Culture and Curriculum, 28(1), 74-89.

https://doi.org/10.1080/07908318.2014.1000926

Lin, A. M. Y., \& He, P. (2017). Translanguaging as dynamic activity flows in CLIL classrooms. Journal of Language, Identity and Education, 16(4), 228-244.

https://doi.org/10.1080/15348458.2017.1328283

Lipski, J. M. (2005). Code-Switching or borrowing? No sé so no puedo decir, you know. Proceedings of the second workshop on Spanish sociolinguistics, 1-15. Cascadilla Proceedings Project Somerville, MA.

https://doi.org/10.1075/itl.83-84.09sch

Littlewood, W., \& Yu, B. (2011). First language and target language in the foreign language classroom. Language Teaching, 44(1), 64-77.

https://doi.org/10.1017/S0261444809990310

Lorenzo, F. \& Moore, P. (2010). On the natural emergence of language structures in CLIL: towards a theory of European educational bilingualism. In Dalton-Puffer, C.; Nikula, T. \& Smit, U. (Eds.), Language use and Language 
Learning in CLIL Classrooms, 23-38. John Benjamins. https://doi.org/10.1075/aals.7.02lor

Marian, V. \& Kaushanskaya, M. (2007). Cross-linguistic transfer and borrowing in bilinguals. Applied Psycholinguistics, 28(2), 369-390.

https://doi.org/10.1017/s014271640707018x

Maxwell-Reid, C. (2010). Content and Language Integrated Learning (CLIL): The influence of studying through English on Spanish students' first-language written discourse. Text and Talk, 30(6), 679-699.

https://doi.org/10.1515/TEXT.2010.033

Meriläinen, L., Riionheimo, H., Kuusi, P., \& Lantto, H. (2016). Loan translations as a language contact phenomenon: Crossing the boundaries between contact linguistics, second language acquisition research and translation studies. Philologia Estonica Tallinnensis, 1, 104-124.

https://doi.org/10.22601/PET.2016.01.07

Moore, P. (2018). Becoming bilingual in the EFL classroom. ELT Journal, 72(2), 130-140.

https://doi.org/10.1093/elt/ccx045

Moore, P. \& Nikula, T. (2016) Translanguaging in CLIL. In Nikula, T., Dafouz, E., Moore, P. \& Smit, U. (Eds.), Conceptualising Integration in CLIL and Multilingual Education, 211-234. Multilingual Matters.

https://doi.org/10.21832/9781783096145-013

Moore, P. \& Turnbull, B. (in press). Emergent bilingualism in foreign language education. In Mohebbi, H. \& Coombe, C. (Eds.), Research questions in language education: A reference guide for teachers. Springer.

Muñoz, C. (2006). Age and the rate of foreign language learning. Multilingual Matters.

https://doi.org/10.1002/j.1545-7249.2008.tb00131.x

Myers-Scotton, C. (1995). Duelling Languages: grammatical structure in codeswitching. Language, 71(1), 135-140.

https://doi.org/10.2307/415966

Navés, T., Miralpeix, I., \& Celaya, M.L. (2005). Who transfers more... and what? Crosslinguistic influence in relation to school grade and language dominance in EFL. International Journal of Multilingualism, 2(2), 113-134.

https://doi.org/10.1080/14790710508668380

Nikula, T., \& Moore, P. (2019). Exploring translanguaging in CLIL. International Journal of Bilingual Education and Bilingualism, 22(2), 237-249.

https://doi.org/10.1080/13670050.2016.1254151
Otheguy, R., García, O., \& Reid, W. (2015). Clarifying translanguaging and deconstructing named languages: A perspective from linguistics. Applied Linguistics Review, 6(3), 281-307.

https://doi.org/10.1515/applirev-2015-0014

Oxford, R. (1994). Language learning strategies: an update. ERIC Digest.

https://eric.ed.gov/?id=ED376707

Pavlenko, A., \& Jarvis, S. (2002). Bidirectional transfer. Applied Linguistics, 23(2), 190-214.

https://doi.org/10.1093/applin/23.2.190

Pavón Vázquez, V., \& Ramos Ordóñez, M. del C. (2019). Describing the use of the L1 in CLIL: an analysis of L1 communication strategies in classroom interaction. International Journal of Bilingual Education and Bilingualism, 22(1), 35-48.

https://doi.org/10.1080/13670050.2018.1511681

Pena Díaz, C., \& Porto Requejo, M. D. (2008). Teacher beliefs in a CLIL education project. Porta Linguarum, 10, 151-161.

https://doi.org/10.30827/Digibug.31786

Psaltou-Tzoysy, A., Alexiou, T., \& Mattheoudakis, M. (2014). Language learning strategies in CLIL and nonCLIL classes. Thessaloniki: Aristotle University of Thessaloniki.

San Isidro, X., \& Lasagabaster, D. (2018). Code-switching in a CLIL multilingual setting: A longitudinal qualitative study. International Journal of Multilingualism, 16(3), 336-356.

https://doi.org/10.1080/14790718.2018.1477781

Sankoff, D., Poplack, S., \&Vanniarajan, S. (1990). The case of the nonce loan in Tamil. Language Variation and Change, 2(1), 71-101.

https://doi.org/10.1017/S0954394500000272

Schmid, S. (1993). Learning Strategies for closely related languages: On the Italian spoken by Spanish immigrants in Switzerland. In Kettemann, B. \& Wieden, W. (Eds.), Current Issues in European Second Language Acquisition Research, 405-418. Gunter Narr Verlag.

https://doi.org/10.5167/uzh-112598

Seidlhofer, B. (2003). A Concept of International English and related issues: from 'real' English to realistic English. Strasbourg: Language Policy Division, Council of Europe.

Skinnari, K., \& Nikula, T. (2017). Teachers' perceptions 
on the changing role of language in the curriculum. European Journal of Applied Linguistics, 5(2), 223-244. https://doi.org/10.1515/eujal-2017-0005

Tsuchiya, K. (2019). Translanguaging Performances in a CLIL Classroom at a Japanese University. In Tsuchiya, K. \& Pérez Murillo, M. (Eds.), Content and Language Integrated Learning in Spanish and Japanese Contexts, 263-284. Palgrave Macmillan.

https://doi.org/10.1007/978-3-030-27443-6_11

William, D. \& Leahy, S. (2015). Embedding Formative Assessment: Practical Techniques for K-12 Classrooms. Learning Sciences International. 